\title{
Erratum to: Metal distributions in seawater, sediment and marine benthic macroalgae from the South Australian coastline
}

\author{
S. Chakraborty $\cdot$ G. Owens
}

Published online: 20 February 2015

(C) Islamic Azad University (IAU) 2015

Erratum to: Int. J. Environ. Sci. Technol. (2014)

11:1259-1270

DOI 10.1007/s13762-013-0310-4

\section{Inclusion of a misleading statement}

On p. 1261 (Seaweed sampling and preparation), the article states that "Algal species were identified by staff from the State Herbarium of South Australia, and voucher specimens prepared and deposited in their permanent collection." This gives the wrong impression that all of the algae were identified by the State Herbarium, when in fact, due to the poor condition of the provided samples, being partially dehydrated and not whole plants, Herbarium staff were only able to confidently identify two algae species $(H$. cuneformis from Port Pirie and C. cephalornithos from Port Broughton). Thus, due to the poor condition of the samples, only five of the eight samples presented for identification were given voucher numbers. In addition, the identification of Blidingia marginata was made with some doubt by $\mathrm{R}$

The online version of the original article can be found under doi:10.1007/s13762-013-0310-4.

S. Chakraborty · G. Owens $(\bowtie)$

Centre for Environmental Risk Assessment and Remediation,

University of South Australia, Mawson Lakes, SA 5095,

Australia

e-mail: Gary.owens@unisa.edu.au

S. Chakraborty

Environmental Science and Engineering Group, Birla Institute of Technology, Mesra, Ranchi, India

G. Owens

Mawson Institute, University of South Australia, Mawson Lakes, SA 5095, Australia
Baldock due to the sample being contaminated with rotted sea grass.

The authors wish to apologise sincerely for giving the wrong impression that State Herbarium staff were responsible for any inaccuracies in algae identification and were not party to the many typographical errors within the paper.

The statement should more correctly state:

"Two algal species (H. cuneformis from Port Pirie and $C$. cephalornithos from Port Broughton) were identified by staff from the State Herbarium of South Australia, and five voucher specimens prepared and deposited in their permanent collection. Blidingia marginata from Port Pirie was provisionally identified with some doubt due to the poor condition of the sample and no voucher specimen was prepared. All other species were identified independently by Dr. Chakraborty."

On p. 1268 (Acknowledgments), the statement "We thank Dr. Gurgel and R. N. Baldock from the State Herbarium of South Australia for identification of the algae." should read "We thank Dr. Gurgel and R. N. Baldock from the State Herbarium of South Australia for identification of some of the algae."

\section{Algae misidentification}

In addition, private communications with the State Herbarium (Dr. Gurgel and R. N. Baldock) have indicated that some identifications of the other algal species presented in the paper may be blatantly incorrect. For example, Acrosorium polyneurum and Gelidium micropterum are not present in Australia and Sargassum cinctum is only present in Queensland, while Anotrichium tenue, which was listed as the species from Port Adelaide, may actually be another red filamentous algae, Polysiphonia sp. which is more prominent in this region. 


\section{Typographical and spelling errors}

We have also been recently made aware of many significant typographical errors in the manuscript that we believe should be corrected. Many of these relate to the incorrect spelling of the algal species studied.

On p. 1259 (Abstract) and later on p. 1268: "Blindigia" should read "Blidingia".

On p. 1259 (Abstract): "twelve species" should be "thirteen species".

On p. 1259 (Keywords): "Blindigia marginate" should read "Blidingia marginata".

On p. 1259 (Abstract): "Cystophora Cephalornithos" should read "Caulocystis cephalornithos".

On p. 1259 (Abstract), p. 1265, p. 1266 (Table 3), p. 1267 (Table 4), and p. 1268: "monillifera" should read "monilifera".
On p. 1259 (Abstract), p. 1266 (Table 3) and p. 1267 (Table 4): "monilliformis" should read "moniliformis".

On p. 1259 (bottom of the page): "environmental" should read "environment".

On p. 1267: There are two instances where "cueniformis" should read "cuneiformis"

On p. 1266: "Hormophysac." should have been abbreviated " $H$. cuneiformis" or have been written in full as "Hormophysa cuneiformis".

On p. 1266: "Ulva.," should have read "Ulva," since the full stop is not required.

On p. 1266: "Enterromorpha." should have read "Enteromorpha". 